\title{
A SINGLE BLIND, PLACEBO-CONTROLLED RANDOMIZED STUDY OF THE SAFETY, REACTOGENICITY AND IMMUNOGENICITY OF THE "EPIVACCORONA" VACCINE FOR THE PREVENTION OF COVID-19, IN VOLUNTEERS AGED 18-60 YEARS (PHASE I-II)
}

\author{
A.B. Ryzhikova , E.A. Ryzhikov ${ }^{\mathrm{b}}$, M.P. Bogryantseva ${ }^{a}$, S.V. Usova ${ }^{a}$, E.D. Danilenko ${ }^{a}$, \\ E.A. Nechaeva ${ }^{a}$, O.V. Pyankova , O.G. Pyankova ${ }^{a}$, A.S. Gudymo ${ }^{a}$, S.A. Bodneva \\ G.S. Onkhonova ${ }^{a}$, E.S. Sleptsova ${ }^{b}$, V.I. Kuzubov', N.N. Ryndyuk ${ }^{c}$, Z.I. Ginko ${ }^{c}$, \\ V.N. Petrov"a, A.A. Moiseeva ${ }^{a}$, P.Yu. Torzhkova ${ }^{a}$, S.A. Pyankov ${ }^{a}$, T.V. Tregubchak ${ }^{a}$, \\ D.V. Antonec ${ }^{\text {, E.V. Gavrilova }}{ }^{\text {, }}$ R.A. Maksyutov ${ }^{a}$
}

${ }^{a}$ State Scientific Center of Virology and Biotechnology "Vector" of Rospotrebnadzor, Koltsovo, Novosibirsk Region, Russian Federation ${ }^{b}$ LLC "EpiVac", Koltsovo, Novosibirsk Region, Russian Federation

${ }^{c}$ Medical Unit No. 163 of the Federal Medical and Biological Agency of Russia, Koltsovo, Novosibirsk Region, Russian Federation

\begin{abstract}
Vaccination of the population is one of the most effective countermeasures in responding to the pandemic caused by novel coronavirus infection. Therefore, scientists all over the world have been working to develop effective and safe vaccines. We have developed a synthetic peptide vaccine, EpiVacCorona, against novel SARS-CoV-2 coronavirus, which is a suspension for intramuscular administration containing a composition of chemically synthesized peptide immunogens of the $\mathrm{S}$ protein of SARS-CoV-2 coronavirus conjugated to a carrier protein and adsorbed on aluminum hydroxide. Phase I-II clinical trials of the vaccine have started that consist of two stages: Stage 1 is an open study of the safety, reactogenicity, and immunological activity of the vaccine with the involvement of 14 volunteers aged 18-30 years; Stage 2 is a single blind, comparative, randomized placebo-controlled study with the involvement of 86 volunteers. The study involved volunteers aged 18-60 years; the vaccine was injected intramuscularly twice, spaced 21 days apart between injections. All local reactions in response to vaccine administration were mild, such as a short-term pain at the injection site. There were no signs of development of local or systemic adverse reactions. The two-dose vaccination scheme induced the production of antibodies, specific to the antigens that make up the vaccine, in $100 \%$ of the volunteers. Seroconversion with a neutralizing antibody titer $\geq 1: 20$ was reported in $100 \%$ of the volunteers 21 days following
\end{abstract}

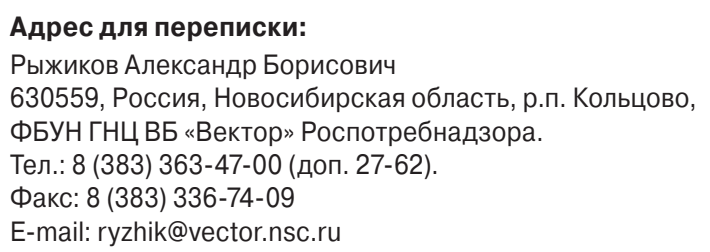

\section{Для цитирования:}

Рыжиков А.Б., Рыжиков Е.А., Богрянцева М.П., Усова С.В.,

Даниленко Е.Д., Нечаева Е.А., Пьянков О.В. , Пьянкова О.Г., Гудымо А.С. Боднев С.А., Онхонова Г.С., Слепцова Е.С., Кузубов В.И., Рындюк Н.Н., Гинько З.И., Петров В.Н., Моисеева А.А., Торжкова П.Ю., Пьянков С.А., Трегубчак Т.В., Антонец Д.В., Гаврилова Е.В., Максютов Р.А. Простое слепое плацебо-контролируемое рандомизированное исследование безопасности, реактогенности и иммуногенности вакцины «ЭпиВакКорона» для профилактики COVID-19 на добровольцах в возрасте 18-60 лет (фаза I-ІІ) // Инфекция и иммунитет. 2021. Т. 11, № 2. С. 283-296. doi: 10.15789/2220-7619-ASB-1699

\section{Contacts:}

Aleksandr B. Ryzhikov

630559, Russian Federation, Novosibirsk Region, Koltsovo, State Scientific Center of Virology and Biotechnology "Vector". Phone: +7 (383) 363-47-00 (add. 27-62). Fax: +7 (383) 336-74-09. E-mail:ryzhik@vector.nsc.ru

\section{Citation:}

Ryzhikov A.B., Ryzhikov E.A., Bogryantseva M.P., Usova S.V., Danilenko E.D. Nechaeva E.A., Pyankov O.V., Pyankova O.G., Gudymo A.S., Bodnev S.A., Onkhonova G.S., Sleptsova E.S., Kuzubov V.I., Ryndyuk N.N., Ginko Z.I., Petrov V.N., Moiseeva A.A., Torzhkova P.Yu., Pyankov S.A., Tregubchak T.V., Antonec D.V., Gavrilova E.V., Maksyutov R.A. A single blind, placebo-controlled randomized study of the safety, reactogenicity and immunogenicity of the "EpiVacCorona" Vaccine for the prevention of COVID-19, in volunteers aged 18-60 years (phase I-II) // Russian Journal of Infection and Immunity = Infektsiya i immunitet, 2021 , vol. 11, no. 2, pp. 283-296. doi: 10.15789/2220-7619-ASB-1699 
the second immunization dose. No seroconversion was reported in the groups of volunteers vaccinated with a placebo. The peptide-based EpiVacCorona Vaccine has low reactogenicity and is a safe, immunogenic product. Clinical Trials Identifier: NCT04527575.

Key words: EpiVacCorona, peptide vaccine, clinical trials, COVID-19, coronavirus.

\section{ПРОСТОЕ СЛЕПОЕ ПЛАЦЕБО-КОНТРОЛИРУЕМОЕ РАНДОМИЗИРОВАННОЕ ИССЛЕДОВАНИЕ БЕЗОПАСНОСТИ, РЕАКТОГЕННОСТИ И ИММУНОГЕННОСТИ ВАКЦИНЫ ЭПИВАККОРОНА" ДЛЯ ПРОФИЛАКТИКИ COVID-19 НА ДОБРОВОЛЬЦАХ В ВОЗРАСТЕ 18-60 ЛЕТ (ФАЗА І-II)}

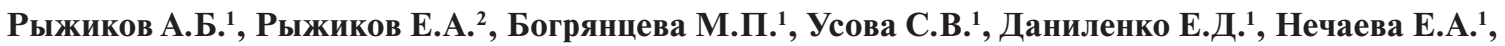
Пьянков О.В. ${ }^{\text {, }, ~ П ь я н к о в а ~ О . Г . ~}{ }^{1}$, Гудымо А.С. ${ }^{1}$, Боднев С.А. ${ }^{1}$, Онхонова Г.С. ${ }^{1}$, Слепцова Е.С. ${ }^{2}$, Кузубов В.И. ${ }^{3}$, Рындюк Н.Н. ${ }^{3}$, Гинько З.И. ${ }^{3}$, Петров В.Н. ${ }^{1}$, Моисеева А.А. ${ }^{1}$, Торжкова П.Ю. ${ }^{1}$, Пьянков С.А. ${ }^{1}$, Трегубчак Т.В. ${ }^{1}$, Антонец Д.В. ${ }^{1}$, Гаврилова Е.В. ${ }^{1}$, Максютов Р.А. ${ }^{1}$

${ }^{l}$ ФБУН ГНЦ ВБ«Вектор» Роспотребнадзора, p.n. Кольцово, Новосибирская область, Россия ${ }^{2}$ ООО «ЭпиВак», р.n. Кольцово, Новосибирская область, Россия

${ }^{3}$ ФГБУЗ Медико-санитарная часть № 163 ФМБА, р.п. Кольцово, Новосибирская область, Россия

Резюме. Вакцинация населения - одна из наиболее эффективных мер противодействия пандемии, вызванной новой коронавирусной инфекцией. Поэтому ученые всего мира работают над созданием эффективных и безопасных вакцин. Мы разработали синтетическую пептидную вакцину «ЭпиВакКорона» против нового коронавируса SARS-CoV-2, которая представляет собой суспензию для внутримышечного введения, содержащую композицию химически синтезированных пептидных иммуногенов S-белка коронавируса SARS-CoV-2, конъюгированных с белком-носителем, и адсорбируется на гидроксиде алюминия. В настоящее время проводятся I-II фазы клинических испытаний вакцины, которые состоят из двух этапов: этап 1 открытое исследование безопасности, реактогенности и иммунологической активности вакцины с участием 14 добровольцев в возрасте 18-30 лет, этап 2 - простое слепое сравнительное рандомизированное плацебоконтролируемое исследование с участием 86 добровольцев. В исследовании приняли участие добровольцы в возрасте 18-60 лет, вакцину вводили внутримышечно дважды с интервалом 21 день между инъекциями. Все местные реакции на введение вакцины были умеренными, например кратковременная боль в месте инъекции. Признаков развития местных или системных побочных реакций не было. Схема двухдозовой вакцинации вызвала выработку антител, специфичных к антигенам, из которых состоит вакцина, у $100 \%$ добровольцев. Сероконверсия с титром нейтрализующих антител $\geq 1: 20$ была зарегистрирована у $100 \%$ добровольцев через 21 день после второй дозы иммунизации. В группах добровольцев, вакцинированных плацебо, о сероконверсии не сообщалось. Вакцина «ЭпиВакКорона» на основе пептидов имеет низкую реактогенность, является иммуногенным и безопасным продуктом. Clinical Trials Identifier: NCT04527575.

Ключевые слова: ЭпиВакКорона, пептидная вакцина, клинические исследования, СОVID-19, коронавирус.

\section{Introduction}

Over the past two decades, coronaviruses have caused epidemic outbreaks of two respiratory diseases: Middle East Respiratory Syndrome and Severe Acute Respiratory Syndrome [3, 15]. In late 2019, a new virus type was detected in China that was able to transmit from human to human causing an outbreak of viral pneumonia [25]. The emergence of novel coronavirus confirms that diseases caused by this group of viruses are a threat to global public health since the virus has spread almost all over the world within a short period of time. On March $11^{\text {th }}$ of 2020 , the WHO declared the novel coronavirus a pandemic.

The current situation associated with the ongoing COVID-19 pandemic brings up the question of the need to rapidly develop countermeasures, among which one of the most important measures is the availability of an effective and safe vaccine [10]. Currently, the development of prophylactic products against COVID-19 is underway around the world based on the following technological platforms: subunit, vector replicating, and vector non-replicating, RNA and DNA vaccines; inactivated, live attenuated, and virus-like particle-based vaccines [9].

We have developed EpiVacCorona Vaccine, containing chemically synthesized peptide immunogens corresponding to selected protective epitopes of SARS-CoV-2 coronavirus $\mathrm{S}$ protein, conjugated to recombinant SARS-CoV-2 protein $\mathrm{N}$, used as a carrier, adjuvanted with aluminum hydroxide. Currently, the Phase I-II clinical trial of the EpiVacCorona Vaccine is underway, i. e. a study of safety, reactogenicity and immunogenicity indicators of the vaccine in volunteers aged 18-60 years. This paper summarizes interim research findings.

The main trials tasks are: evaluation of EpiVacCorona Vaccine safety when administered twice intramuscularly; evaluation of reactogenicity and adverse reactions to vaccine administration; and investigation of immune responses following two doses of EpiVacCorona Vaccine in comparison to placebo. 


\section{Materials and methods}

\section{Trial design}

The study was carried out at the Federal State Budgetary Health Institution - Medical and Sanitary Unit No. 163, Federal Medical and Biological Agency (FSBHI MSU-163, FMBA of Russia).

The first phase was an open trial. This study enrolled 14 men and women, aged 18 to 30 years inclusive, who meet the inclusion criteria and have no exclusion criteria, whose data will be used for subsequent analysis of safety and immunogenicity. The second phase was a simple, blind, placebo-controlled, randomized, parallel-group study. The study enrolled 86 men and women, aged 18 to 60 years inclusive, who meet the inclusion criteria and have no exclusion criteria (Fig. 1). Prior to all study procedures, written informed consent was obtained from the subjects towards their inclusion in the study. Inclusion criteria: the study enrolled volunteers of both sexes with a body mass index from 18.5 to $30 \mathrm{~kg} / \mathrm{m}^{2}$. When collecting anamnestic data and human-subjective data of the volunteers, no chronic diseases, serious concomitant diseases, pathological conditions, or acute infectious diseases were reported. No data on a positive allergic anamnesis or drug intolerance was reported. During the study period, as well as 7 weeks or less before immunization, the volunteers did not take any drugs influencing the parameters of the immune system. At the screening stage, no deviations in the vital parameters (blood pressure, heart rate, respiratory rate, body temperature) were reported in the volunteers.
When testing blood serum samples from volunteers for the presence of antigen to hepatitis B (HBsAg), antibodies to HIV and those to hepatitis C, and for the presence of the causative agent of syphilis, negative results were obtained. Determination of $\mathrm{A}, \mathrm{M}$, and $\mathrm{G}$ class antibodies specific to SARS-CoV-2 was conducted by ELISA. At the screening stage, antibodies, as well as SARS-CoV-2 coronavirus RNA in nasopharyngeal swabs, were absent in all volunteers.

Exclusion criteria were the following: contacts with COVID-19 patients for 14 days prior to the start of the clinical trial; hypersensitivity to any component of the vaccine and the history of allergic reactions to any vaccination in the past; the history of serious post-vaccination reactions/complications; pregnancy and breastfeeding; military personnel on conscription; symptoms of any disease at the time of inclusion in the study or if it has passed less than 4 weeks since recovery; the history of any acute respiratory disease within less than 3 months prior to inclusion in the study; the history of tuberculosis, cancer, autoimmune diseases, skin diseases (pemphigus, psoriasis, eczema, atopic dermatitis); long-term use (more than 14 days) of immunosuppressive drugs, systemic glucocorticosteroids or immunomodulatory drugs within 6 months prior to the study; vaccination with any vaccine within one month prior to inclusion; taking immunoglobulin drugs or blood products within last 3 months prior to the study; donation of $450 \mathrm{ml}$ or more of blood or plasma within less than 2 months prior to the study; participation in other clinical trials within less than 3 months

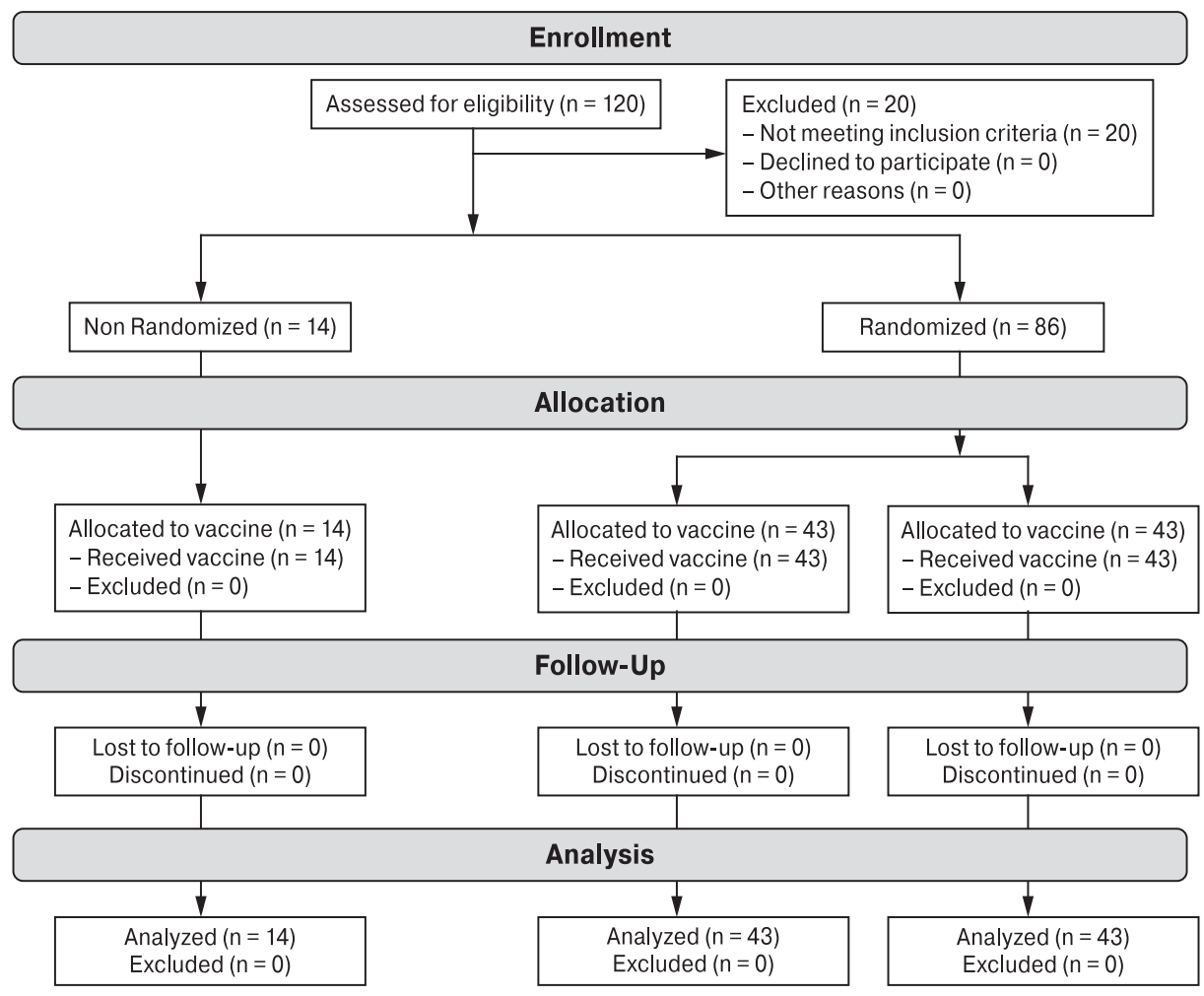

Figure1. Clinical trial flow diagram 
prior to the study; alcohol or drug addiction; taking more than 10 units of alcohol per week; positive test for HIV, viral hepatitis B and C, lues venerea; false inclusion (violation of inclusion and non-inclusion criteria) or the appearance of non-inclusion criteria during the study; exclusion due to a clinically significant deviation from the protocol/violation of the protocol; and/or refusal of a volunteer to continue.

The volunteers were divided into groups after receiving examination results (medical history, physical and laboratory and imaging examination). At the first stage, the study was carried out with the involvement of 14 volunteers included in one group (Group 1). The vaccine was not coded. The vaccine was administered intramuscularly to the first volunteer who was then followed up for 72 hours (i. e. Stop-time period); in the event of no adverse events in the first volunteer, the second volunteer was vaccinated. Then there followed the Stop-time period, and 72 hours later the vaccine was administered to the third volunteer; then following 72 hours - to the fourth; and following another 72 hours - to the fifth volunteer. Seventy two (72) hours following the vaccination of the $5^{\text {th }}$ volunteer, the first vaccination of the remaining 9 volunteers was performed. The second injection was performed 21 days following the first administration of the vaccine. The second stage is a single blind, comparative, randomized, placebo-controlled study. Eighty-six (86) volunteers were divided into two groups by block randomization in a 1:1 ratio (randomization by the "sealed envelope" method): Group 2 received the EpiVacCorona Vaccine (43 subjects); Group 3 received a placebo (43 subjects). All volunteers were admitted to a hospital the day before the first vaccination. The time of hospital stay was 23 days. For the sake of objectification, the volunteers did not know what study preparation was administered to them. The study preparations were delivered to the trial facility in a ready-to-use (coded) form. To ensure masking, before injection, the study preparations were prepared in a treatment room behind a screen. No special compliance measures were required to receive the study preparation as the study preparation was administered at the medical facility by the facility's trial center staff. The investigator physician, by opening an envelope with the lowest number in the set, knew which randomization number should be assigned and which study preparation should be administered to the volunteer. When the next volunteer was included in the study, the next envelope was opened.

The primary outcome measures were the proportions of vaccinated volunteers who do not have any laboratory-confirmed symptoms of SARS-CoV-2 in combination with one or more of the following symptoms: fever or chills; cough; shortness of breath or labored breathing; fatigue; muscle pain; headache; loss of taste or smell; sore throat; nasal congestion or runny nose; nausea or vomiting; and diarrhea within 9 months of vaccination versus a placebo. The sec- ondary outcome measures were the following: the proportion of volunteers with an increase in the level of immune response in the form of geometric mean titers of specific antibodies in ELISA; and a specific neutralizing antibody titer $\geq 1: 2042$ days after the first vaccination and 90, 180, and 270 days after the first vaccination versus a placebo.

The Clinical Study Protocol was reviewed at a meeting of the local Ethics Committee at FSBHI MSU-163, FMBA of Russia, where the clinical study was carried out (meeting minutes of July 25, 2020). The study was approved by the Ethics Board of the Russian Federation Ministry of Health (extract from the minutes of the Ethics Board meeting No. 376 of July 24, 2020). The study was conducted in accordance with the ethical principles of the Declaration of Helsinki originally adopted by the 18th session of the World Medical Association (1964), revised in 2013. During the clinical study "A single blind, placebo-controlled randomized study of the safety, reactogenicity and immunogenicity of a peptide antigen-based vaccine for the prevention of COVID-19 (EpiVacCorona), in volunteers aged 18-60 years (Phase I-II)", no modifications were made to the Study Protocol. All procedures (physical examination, clinical tests, immunological study, and detection of adverse events) were carried out in accordance with Protocol No. COV/pept-01/20 (Version 2 of 22.07.2020). The study began on July 26, 2020, and it will be completed on May 18, 2021

\section{Vaccine and placebo}

Viral protein $\mathrm{S}$, which is expressed on virion surface and forms homotrimers, is a promising target for the development of vaccines against the novel coronavirus. SARS-CoV-2 protein $\mathrm{S}$ consists of two subunits. The S1 subunit provides binding of the virus to ACE2 receptor located on the target cell membrane. The S2 subunit ensures fusion of the virion envelope and the target cell membrane. Blocking of receptor binding and cell membrane fusion functions can provide protection against viral infection. However, the development of SARS-CoV-2 vaccines using the complete molecular structure of viral S protein has a number of potential caveats, and the most serious one is antibody-dependent enhancement of infection, as previously shown for SARS-CoV-1 spike protein by a group of Chinese scientists [22].

Therefore, we considered an alternative approach that provides the development of protective immunity and excludes the possibility of antibody-dependent enhancement of infection. We used the technology of synthetic peptide vaccines, which includes in silico design of several immunoactive peptide fragments representing the cognate viral antigen, chemical synthesis of peptides, followed by conjugation to a highmolecular carrier protein. The most effective constructs were selected for inclusion into the candidate peptide vaccine formulation after studying their im- 
munogenicity, antigenic specificity and protectivity in animal models (data not shown).

Peptide selection was based on published spatial structures of homologous SARS-CoV-1 spike protein and on actual genetic sequences data of novel coronavirus SARS-CoV-2 [5, 19]. Epitopes located near the sites vital for the virus were designed using original computer simulation methods. The design excluded epitopes that can lead to antibody-dependent enhancement of infection (e.g. peptide S597-603) or have local antigenic similarity to human proteins $[7,11,12$, 22]. In order to ensure the robustness of the vaccine to possible mutations of the virus, which would entail changes in antigenic properties, epitopes were selected from the most conserved regions of the $S$ protein $[7$, 12]. Synthesized peptides were covalently bound to the carrier protein. The carrier protein MBP-6xHis-N nCoV-2019 contains the structures of SARS-CoV-2 $\mathrm{N}$ protein, the $E$. coli maltose binding protein (MBP), and the 6xHis-tag required for purification with metal chelate affinity chromatography. SARS-CoV-2 N protein was chosen since it is well-conserved and contains virus-specific T-cell epitopes and thus should be also involved in production of memory $\mathrm{T}$ cells. After the purification stage, the carrier protein is covered with covalently bound peptides and adsorbed on aluminum hydroxide used as adjuvant.

The EpiVacCorona Vaccine is a suspension for intramuscular injection. The EpiVacCorona Vaccine was developed and manufactured by FBRI SRC VB VECTOR, Rospotrebnadzor (Russia, Koltsovo) (GMP-0112-000170/17).

The vaccine was injected intramuscularly twice, given 21 days apart in a single vaccination dose of $(225 \pm 45) \mu \mathrm{g} / 0.5 \mathrm{ml}$ into the deltoid muscle using sterile syringes (Vogt Medical, Germany). As a placebo, sodium chloride solution (a $0.9 \%$ solution for the preparation of dosage forms for injections) was administered intramuscularly twice, spaced 21 days apart at a dose of $0.5 \mathrm{ml}$.

The vaccine and the placebo were stored at a temperature of $2^{\circ} \mathrm{C}$ to $8^{\circ} \mathrm{C}$.

\section{Physical examination and clinical laboratory procedures}

Physical examinations, biochemical, immunological and hematological blood parameters, clinical urine test were performed according to standard clinical protocols. The examination schedule and all the assessed parameters are shown in Supplementary Table 1.

Physical examination was carried out according to the standard practice and included a survey, identification of complaints and symptoms, measurements of body temperature, blood pressure, heart rate and respiratory rate (these indicators were measured after the volunteer rested for 5 minutes in a sitting position). Examination of the volunteers also included examination of skin and mucous membranes (eyes, mouth and pharynx), auscultation, pulmonary percussion, palpation of the abdominal organs and lymph nodes.

\section{Safety and reactogenicity study}

The safety of the vaccine was assessed by the frequency and type of adverse events during the study: immediate-type adverse events (allergic reactions) that occur within 2 hours after vaccination and that are identified both by the investigator physician and by information provided by the volunteer; adverse events (local and systemic reactions) that occur within 7 days after vaccination and that are identified both by the investigator physician and by data provided by the volunteer; or other adverse events that occur 7 days after each vaccination (from 8 to 42 days after the first vaccination, excluding the allowable interval of visits) and that are noted by the volunteer in the Subject (Self-observation) Diary. The frequency of serious adverse events during the study was recorded. Vital signs (temperature, blood pressure, heart rate, respiratory rate) were assessed. A physical examination and a study of biochemical and hematological parameters was performed, and significant deviations were recorded.

The usual post-vaccination reactions of the body are divided into local and systemic reactions [1, 17]. The local symptoms include hyperemia, edema, soreness, infiltrate formation, and itching at the injection site. The system reactions include fever, malaise, headache, myalgia, etc. The local and systemic reactions were assessed on a 4-point scale [23]. Body temperature was measured twice a day (in the morning and in the evening), and it was recorded in the Subject Diary and in the individual registration card. The vaccine is considered reactogenic if moderate or strong local reactions or catarrhal phenomena lasting more than 3 days are reported in more than one out of 50 vaccinated individuals [2].

The adverse events identified during the study were grouped into frequency tables according to type, severity, and association with the vaccine under study. The proportions of patients with laboratory test values exceeding physiological norms were also assessed to compare the groups under the study

\section{ELISA serum assays}

EpiVacCorona Vaccine specific antibodies were identified using ELISA test system "Vector ELISA Corona-Ab", TU 21.10.60-092-05664012-2020. Virusspecific antibodies were identified using beta-propiolactone inactivated SARS-CoV-2 virus, strain $\mathrm{nCoV} /$ Victoria/1/2020, propagated in Vero E6 cells. Immunosorbent was a 96-well polystyrene plate of high sorption capacity containing an immobilized inactivated natural SARS-CoV-2 antigen. Inactivation of the virus was performed by adding beta-propiolactone to antigens purified by precipitation at a final concentration of $0.5 \%$. The incubation 
is carried out for 2 hours at $4^{\circ} \mathrm{C}$ and stirring. After that, beta-propiolactone is decomposed by heating for 2 hours at $37^{\circ} \mathrm{C}$. For titration, two-fold dilutions of the sera of animals immunized with the vaccine and control animals (not immunized) are prepared in the range of 1:40-1:2560. After incubation for $30 \mathrm{~min}$ at $37^{\circ} \mathrm{C}$, plate wells were washed five times with PBST containing Tween-20. After washing, $100 \mu \mathrm{l}$ of the solution of Staphylococcus aureus protein A conjugated to horseradish peroxidase at a final concentration of $1.26 \mu \mathrm{g} / \mathrm{ml}$ (Biosan, Novosibirsk) was added to the wells. After a 30 -minute incubation at $37^{\circ} \mathrm{C}$, the wells were washed and $0.05 \%$ tetramethylenebenzidine solution was added. The optical density of the solutions was measured at a wavelength of $450 \mathrm{~nm}$. The antibody titer is the maximum dilution of studied serum at which the optical density of the solution exceeds the average optical density of the negative control.

\section{Virus neutralization assays}

The studied serum samples were thermally inactivated for $30 \mathrm{~min}$ at $56^{\circ} \mathrm{C}$ prior to virus neutralization assay. Sterile round-bottom plates were used to prepare serial two-fold dilutions of the studied sera in a cell culture medium (DMEM, $100 \mathrm{U} / \mathrm{ml}$ benzylpenicillin, $100 \mu \mathrm{g} / \mathrm{ml}$ streptomycin, $300 \mu \mathrm{g} / \mathrm{ml}$ L-glutamine, 2\% fetal bovine serum [Invitrogen]). The viral suspension containing 200 FFU of SARSCoV-2 (strain nCoV/Victoria/1/2020) was added to each well of the plate, except negative controls, with subsequent incubation for $1 \mathrm{~h}$ at $37^{\circ} \mathrm{C}$. Vero E6 monolayer of more than $90 \%$ confluence in flatbottomed 96 -well cell culture plate was washed twice with the cell culture medium, and $100 \mu 1$ of viral suspension was transferred from a round-bottom plate with serum dilutions to the corresponding wells of the plate with the cell monolayer. After incubation for 1 hour at $37^{\circ} \mathrm{C}$ and $5 \% \mathrm{CO}_{2}$, the medium was removed from the wells and the plate was washed once and $150-\mu 1$ of the medium was added to all wells. After $18-20$ hours of incubation at $37^{\circ} \mathrm{C}$ and $5 \%$ $\mathrm{CO}_{2}$, the medium was removed from the wells, $100 \mu \mathrm{l}$ of $80 \%$ acetone (cooled to minus $20^{\circ} \mathrm{C}$ ) was added. After 10-15 min incubation, acetone was removed, and the plate was washed with phosphate buffered saline (PBS). $100 \mu$ of diluted human monoclonal antibodies to SARS-CoV-2 (Anti-N protein SARSCoV-2 mAb_IgG, "SanyouBiopharmaceuticals", antibodies in PBS ratio 1:2000) was added to each well. The plate was incubated at $37^{\circ} \mathrm{C}$ for 1 hour. The wells were washed with PBS four times, and secondary rabbit antibodies to human $\operatorname{IgG}$ conjugated to horseradish peroxidase (Abcam) were added at a dilution of 1:1000. After 30 minutes of incubation, the wells were washed four times with PBS, and AEC (3-amino-9-ethylcarbazole, Sigma) solution was added. Thirty min later: the solution was removed; the plate was washed once with PBS; the infected cells stained in red-brown were counted in microscope; and the number of focus-forming units (FFUs) was counted. The titer of the neutralizing serum antibodies is a dilution at which the amount of FFU is reduced by $50 \%$ compared to the average value of FFU in control wells.

\section{PCR testing of nasopharyngeal swab}

Isolation of RNA from nasal washes was performed using a "Ribo-sorb" reagent kit (CRIE, Russia) according to the manufacturer's instructions. The synthesis of cDNA from isolated RNA was carried out using a "Reverta-L" (CRIE, Russia) reagent kit for reverse transcription reaction in accordance with the manufacturer's instructions. Amplification of SARS-CoV-2 cDNA fragments, synthesized on SARS-CoV-2 RNA template in reverse transcription reaction, was carried out using VectorPCRRT-COVID-19-RG reagent kit (FBRI SRC VB VECTOR, Russia) according to the manufacturer's instructions. The test results are interpreted as described in the kit's instruction.

\section{Statistical analysis}

Statistical analysis was performed using the Wilcoxon test for paired samples and Mann-Whitney test for unpaired samples. The analysis of dynamical changes of the studied indicators within the groups was performed with Friedman's test followed by Nemenyi's post-hoc test. The statistical significance for categorical variables (changes in seroconversion and infection markers etc.) was determined using Fisher's exact test. The adjustment for multiple testing was performed using the Bonferroni correction. An alpha value of 0.05 or less was considered statistically significant. Statistical analysis was performed using R statistical software [16].

\section{Results}

\section{Trial population}

The clinical trials began on July 26, 2020. The start of the clinical trials was preceded by a stage of screening the health status of the volunteers. The volunteers were divided into groups after receiving examination findings (medical history, physical and laboratory and imaging examination) and deciding whether a volunteer met the inclusion/exclusion criteria. At the first stage, with the involvement of 14 volunteers, an open study of the vaccine's safety, reactogenicity, and immunological activity was carried out (the study began on July 26, 2020).

The percentages of men and women in the group were $64.3 \%$ and $35.7 \%$, respectively. The average age was 25.1 years, and the average weight was $71.8 \mathrm{~kg}$. At the second stage, with the participation of 86 volunteers, a single blind, comparative, randomized, placebo-controlled study was conducted (study started on August 15, 2020). The percentages of men and women in the group receiving the EpiVacCorona 
Vaccine were $60.5 \%$ and $39.5 \%$, respectively. The average age was 35.1 years, and the average weight was $73.7 \mathrm{~kg}$. The percentages of men and women in the placebo group were $48.8 \%$ and $51.2 \%$, respectively. The average age was 31.5 years, and the average weight was $67.9 \mathrm{~kg}$. More details can be found in Table 1 .

\section{Safety outcomes}

The peptide Vaccine EpiVacCorona underwent a toxicity study only in animals and its safety profile for humans was not fully known. Then, according to the recommendations, that is why the vaccination of volunteers was started involving the first 5 participants being vaccinated in turn at 72 hours intervals. In other words, the vaccine was administered intramuscularly to the first volunteer, who was monitored for 72 hours (Stop-time period). In the absence of adverse events in the first volunteer, the second volunteer was vaccinated, etc.

Based on the results of observations obtained in the first five volunteers, the first interim report was provided to the Ministry of Health of the Russian Federation and, 72 hours after the vaccination of the $5^{\text {th }}$ volunteer, the remaining 9 volunteers of the first stage were vaccinated. They were monitored daily for 5 days. After that, based on the results of assessing the local and systemic reactions of all participants in the first stage (14 volunteers), as well as the results of biochemical and hematological blood tests and clinical urine analysis, a second interim report on the safety and reactogenicity of the EpiVacCorona Vaccine was provided. Due to the absence of significant adverse reactions, it was decided to further conduct the study.

Intramuscular administration of the EpiVacCorona Vaccine was characterized by local pain at the injection site after each injection (in 2 out of 14 volunteers, $14.3 \%)$. Symptoms were very mild and transient (1-2 days). No immediate reactions (allergies) were observed. No systemic symptoms, such as headache, myalgia, asthenia, fever, etc., were registered in phase 1. At the same time, the average values of the biochemistry parameters did not go beyond physiological norms, except for one volunteer (i.e. an increase in the creatinine content to $110 \mu \mathrm{mol} / \mathrm{L}$ on the 7th and 14th days after the first vaccination). Vaccination in most of the volunteers did not cause changes in the hematological indicators, except for two cases (14\%) wherein changes in monocyte content were detected on the $3^{\text {rd }}$ day after the first vaccination. When performing spirography, no changes in the parameters of pulmonary function were detected at all times of observation. The ECG remained within normal limits in all the volunteers. The ultrasound investigation of the abdominal organs did not show any pathological changes in the organs examined. No significant changes in physical or laboratory examination results were observed, except observations of ALT/AST activity in biochemical blood assays (Supplementary Table 2). However, these observations were not attributed to vaccination and were not considered clinically significant.

The further study of the safety and reactogenicity of the EpiVacCorona Vaccine was carried out with the involvement of 86 volunteers divided into two groups. One group received the vaccine twice, given 21 days apart. The other group received the placebo using the same scheme. In phase 2, no immediate reactions were observed. The most common adverse reaction was local pain at injection site (observed in 4 out of 43 volunteers after the first injection and in 2 more patients after the second injection). All local reactions were mild and transient (1-2 days). Only one volunteer from the group of vaccinees had a shortterm moderate increase in body temperature 12 hours after the first injection, accompanied by headache and ear pain. The volunteer was placed in an isolation box, where he was kept for 6 days. No viral RNA was isolated upon daily examination of nasopharyngeal swabs. A consultation with an otolaryngologist was arranged, and otitis media was diagnosed with treatment prescribed.

During the entire observation period (24 visits), no significant changes were detected in terms of such indicators as body temperature (all but one, attributed mainly to otitis media), blood pressure, heart rate, or respiratory rate in any volunteer (vaccinated with either EpiVacCorona Vaccine or placebo). All vital indicators were within physiological norms in all periods. Local and systemic reactions are summarized in Table 2.

Increased ALT enzyme activity was detected in 12 volunteers who received EpiVacCorona Vaccine and in 12 individuals from the placebo group. Increased AST activity was observed at least once in 25 vaccinees and in 25 volunteers who received placebo. Increased LDH activity was observed at least once in 11 patients who received the vaccine and in 9 individuals from the placebo group. Increased alkaline phosphatase activity was observed in 9 vaccinees. However, the observed deviations were mild and had no clinical manifestations; they were explained by physiological reasons not related to pathology and not attributed to vaccination. In the study of the biochemical and hematological parameters of the blood, there were no significant differences found between the groups receiving the vaccine and the placebo. The observations of biochemical and hematological test results deviating from cognate physiological norms obtained in different groups, are shown in Supplementary Table 2.

No immediate reactions, and no local or systemic reactions, were observed in patients who received placebo preparation.

No statistically significant changes in AE/SAE frequencies were observed; no statistically significant differences in laboratory examination results were observed between vaccinees and placebo groups at any time. 
Table 1. Trial population characteristics

\begin{tabular}{|c|c|c|c|c|c|c|c|c|c|c|c|}
\hline Variable & Phase & Vaccine & Sex & $\mathbf{N}$ & Min & Max & Mean & SD & Med & Q1 & Q3 \\
\hline$T$ & 1 & 1 & $\mathrm{~F}$ & 5 & 36.4 & 36.8 & 36.64 & 0.18 & 36.7 & 36.5 & 36.8 \\
\hline$T$ & 1 & 1 & $\mathrm{M}$ & 9 & 36.2 & 36.8 & 36.52 & 0.2 & 36.4 & 36.4 & 36.7 \\
\hline $\mathbf{T}$ & II & 0 & $\mathrm{~F}$ & 16 & 36 & 36.9 & 36.69 & 0.26 & 36.75 & 36.6 & 36.9 \\
\hline $\mathbf{T}$ & II & 0 & $\mathrm{M}$ & 27 & 36 & 36.9 & 36.59 & 0.23 & 36.6 & 36.4 & 36.75 \\
\hline$T$ & II & 1 & $F$ & 23 & 36 & 36.9 & 36.59 & 0.27 & 36.7 & 36.5 & 36.8 \\
\hline$T$ & II & 1 & $M$ & 20 & 36.1 & 36.9 & 36.69 & 0.2 & 36.8 & 36.6 & 36.8 \\
\hline Age & I & 1 & $\mathrm{~F}$ & 5 & 18 & 36 & 23.6 & 7.64 & 19 & 19 & 26 \\
\hline Age & I & 1 & $M$ & 9 & 18 & 41 & 26 & 8.06 & 24 & 19 & 28 \\
\hline Age & II & 0 & $\mathrm{~F}$ & 16 & 22 & 59 & 35.31 & 12.42 & 32.5 & 24 & 41.25 \\
\hline Age & II & 0 & $\mathrm{M}$ & 27 & 21 & 52 & 32.81 & 8.23 & 32 & 27.5 & 37.5 \\
\hline Age & II & 1 & $\mathrm{~F}$ & 23 & 19 & 55 & 35.22 & 11.67 & 37 & 23.5 & 42 \\
\hline Age & II & 1 & $M$ & 20 & 18 & 57 & 31.05 & 10.16 & 28 & 23.75 & 36.25 \\
\hline Weight & 1 & 1 & $\mathrm{~F}$ & 5 & 62 & 74 & 67 & 4.9 & 65 & 64 & 70 \\
\hline Weight & 1 & 1 & $M$ & 9 & 70 & 90.3 & 83.28 & 7.31 & 82 & 79.1 & 90 \\
\hline Weight & II & 0 & $F$ & 16 & 48 & 78 & 63.75 & 9.11 & 66 & 58 & 70 \\
\hline Weight & II & 0 & $M$ & 27 & 62 & 97 & 77.85 & 10 & 79 & 68.5 & 86.5 \\
\hline Weight & II & 1 & $\mathrm{~F}$ & 23 & 48 & 84 & 62.32 & 9.5 & 59 & 56 & 69 \\
\hline Weight & II & 1 & $M$ & 20 & 55 & 103 & 79.7 & 10.28 & 77.5 & 74.75 & 84.5 \\
\hline Height & 1 & 1 & $\mathrm{~F}$ & 5 & 160 & 169 & 166 & 3.67 & 168 & 165 & 168 \\
\hline Height & 1 & 1 & $M$ & 9 & 171 & 188 & 180.89 & 6.03 & 182 & 176 & 186 \\
\hline Height & II & 0 & $F$ & 16 & 157 & 177 & 165.06 & 4.67 & 165 & 163.75 & 166.25 \\
\hline Height & II & 0 & $M$ & 27 & 166 & 194 & 180.19 & 6.69 & 180 & 176 & 184.5 \\
\hline Height & II & 1 & $F$ & 23 & 148 & 176 & 164.48 & 5.5 & 165 & 161 & 168 \\
\hline Height & II & 1 & $M$ & 20 & 160 & 195 & 177.9 & 7.83 & 178 & 173.5 & 182.5 \\
\hline SAP & 1 & 1 & $F$ & 5 & 118 & 130 & 124.4 & 5.55 & 124 & 120 & 130 \\
\hline SAP & 1 & 1 & $M$ & 9 & 120 & 130 & 125.11 & 4.01 & 124 & 124 & 130 \\
\hline SAP & II & 0 & $\mathrm{~F}$ & 16 & 110 & 141 & 125.12 & 7.69 & 122 & 120 & 129.5 \\
\hline SAP & II & 0 & $\mathrm{M}$ & 27 & 119 & 139 & 130.07 & 5.58 & 130 & 125.5 & 134.5 \\
\hline SAP & II & 1 & $F$ & 23 & 117 & 137 & 125.04 & 5.84 & 125 & 120 & 128 \\
\hline SAP & II & 1 & $M$ & 20 & 110 & 137 & 125.6 & 7.16 & 125.5 & 120.75 & 130.25 \\
\hline DAP & 1 & 1 & $F$ & 5 & 70 & 80 & 75.8 & 3.63 & 76 & 76 & 77 \\
\hline DAP & 1 & 1 & $M$ & 9 & 78 & 82 & 80 & 1.41 & 80 & 80 & 80 \\
\hline DAP & II & 0 & $F$ & 16 & 63 & 97 & 79.25 & 8.47 & 76.5 & 73.75 & 85.75 \\
\hline DAP & II & 0 & $M$ & 27 & 67 & 95 & 81.85 & 6.27 & 82 & 80 & 85 \\
\hline DAP & II & 1 & $\mathrm{~F}$ & 23 & 63 & 97 & 79.17 & 7.33 & 80 & 75.5 & 83 \\
\hline DAP & II & 1 & $M$ & 20 & 65 & 90 & 78.2 & 6.76 & 77.5 & 73.75 & 81.75 \\
\hline $\mathbf{R R}$ & 1 & 1 & $F$ & 5 & 16 & 18 & 17.6 & 0.89 & 18 & 18 & 18 \\
\hline $\mathbf{R R}$ & 1 & 1 & $M$ & 9 & 16 & 18 & 16.44 & 0.88 & 16 & 16 & 16 \\
\hline RR & II & 0 & $F$ & 16 & 16 & 18 & 16.69 & 0.6 & 17 & 16 & 17 \\
\hline $\mathbf{R R}$ & II & 0 & $M$ & 27 & 15 & 18 & 16.33 & 0.78 & 16 & 16 & 17 \\
\hline $\mathbf{R R}$ & II & 1 & $F$ & 23 & 15 & 18 & 16.57 & 0.66 & 17 & 16 & 17 \\
\hline $\mathbf{R R}$ & II & 1 & $M$ & 20 & 15 & 17 & 16.2 & 0.62 & 16 & 16 & 17 \\
\hline HR & 1 & 1 & $\mathrm{~F}$ & 5 & 74 & 78 & 77.2 & 1.79 & 78 & 78 & 78 \\
\hline HR & 1 & 1 & $\mathrm{M}$ & 9 & 72 & 76 & 74 & 1.73 & 74 & 72 & 76 \\
\hline HR & II & 0 & $F$ & 16 & 66 & 84 & 77.56 & 4.53 & 78 & 75.75 & 82 \\
\hline HR & II & 0 & $M$ & 27 & 68 & 88 & 76.15 & 5.33 & 76 & 72 & 79 \\
\hline HR & II & 1 & $F$ & 23 & 63 & 84 & 75.91 & 5.35 & 77 & 72.5 & 79 \\
\hline HR & II & 1 & $M$ & 20 & 62 & 86 & 74.2 & 7.13 & 73.5 & 71.75 & 77.25 \\
\hline
\end{tabular}

Notes. Variables: T - body temperature, Age (years), Weight $(\mathrm{kg})$, Height (cm), SAP and DAP — systolic and diastolic arterial pressure respectively, $\mathrm{RR}$ - respiratory rate, $\mathrm{HR}$ - heart rate. Vaccine - 1 in EpiVacCorona group and 0 in placebo group. $\mathrm{N}-$ the number of volunteers. Min, Max and Mean - are the minimal, maximal and average values respectively. SD is standard deviation. Med, Q1 and Q2 are the median value and the $1^{\text {st }}$ and the $3^{\text {rd }}$ quartile values. 
The vaccine did not cause the development of immediate adverse events (allergic reactions) occurring within 2 hours after vaccination. The development of serious adverse events was not observed during the study. Thus, the vaccine was considered to be low reactogenic, safe and well-tolerated. The reversible local irritating effect of vaccination, observed in several patients (6 out of 43), was expected due to known effects of the aluminum hydroxide used as an adjuvant in EpiVacCorona formulation.

However, three cases of acute respiratory viral infections were reported during the study, with two of them been laboratory-confirmed as COVID-19. These were the only severe adverse events registered.

One case was an 18 year old patient from the first group of vaccinees (phase 1). On July 30, 2020, he was hospitalized for 23 days at the hospital, and the first vaccination with EpiVacCorona (Series No. K010520) was carried out on August 01, 2020. The second vaccination was on August 22, 2020, and the patient returned back home on August 23, 2020. The scheduled visits took place on August 24, September 28, and October 4, 2020. There were no complaints reported, and no SARS-CoV-2 coronavirus RNA was detected in nasopharyngeal swabs on these dates. On day 45 after the first vaccination, a questionable PCR test result was recorded $(\mathrm{Ct} 33)$. On day 47, a second examination was positive, with a $\mathrm{Ct}$ of 21 . The patient had general malaise, rare dry cough, discharge from the nose, and increased body temperature $\left(38.0^{\circ} \mathrm{C}\right)$. In the pharynx, there was a dull hyperemia of the posterior pharyngeal wall. Heart and lungs were without pathology. According to patient self-report, he felt a deterioration on September 15, 2020 (moderate weakness, loss of smell, a rare dry cough and discharge from the nose appeared). The patient was isolated (lived separately). On September 22, PCR testing results for SARS-CoV-2 were negative.

Another laboratory-confirmed case of COVID-19 was registered in a 50 year old patient who received the placebo. The first placebo administration she got on August 18 and the second on September 7, 2020.
The scheduled visits took place on September 9 and September 15, 2020. There were no complaints reported, and no SARS-CoV-2 coronavirus RNA was detected in nasopharyngeal swabs on these dates. The first signs of the disease (increased body temperature $37.5^{\circ} \mathrm{C}$ and weakness) were recorded appeared on September 17, 2020. However, on September 20, 2020, no symptoms but weakness were recorded: body temperature was $36.6^{\circ} \mathrm{C}$; arterial pressure and heart rate were normal; and breathing sound was clear with no wheezing. On September 24, the temperature had risen to $39.0^{\circ} \mathrm{C}$, and on September 25, 2020, she was admitted to the Regional Clinical Hospital with a diagnosis of bilateral lower lobe pneumonia with SARS-CoV-2 RNA detected in nasopharyngeal swabs. The patient remained at the hospital until October 06, 2020.

Another ARVI case was registered in a 25 year old patient. She got the first placebo injection on August 18 and the second one on September 07. The scheduled visits took place on September 09 and September 15. There were no complaints reported, and no SARS-CoV-2 coronavirus RNA was detected in nasopharyngeal swabs on these dates. The first signs of disease appeared on October 07: body temperature increased to $38.8^{\circ} \mathrm{C}$; general weakness and myalgia were reported. The hyperthermia persisted for 3 days. No SARS-CoV-2 RNA was detected.

The diseased volunteer from the placebo group with laboratory-confirmed COVID-19 disease developed a bilateral pneumonia. Clinical symptoms in the vaccinated volunteer were much less pronounced, but this could also be explained by the fact that, in general, younger people have mild disease.

\section{Immunogenicity outcomes}

An enzyme-linked immunosorbent assay was used to assess the specific antibody response to EpiVacCorona antigens and the antigens of a native SARS-CoV-2. The highest seroconversion rate $(100 \%)$ for the vaccine antigen was reported on day 42 following the first injection of EpiVacCorona with geo-

Table 2. Local and systemic adverse reactions summary throughout the study

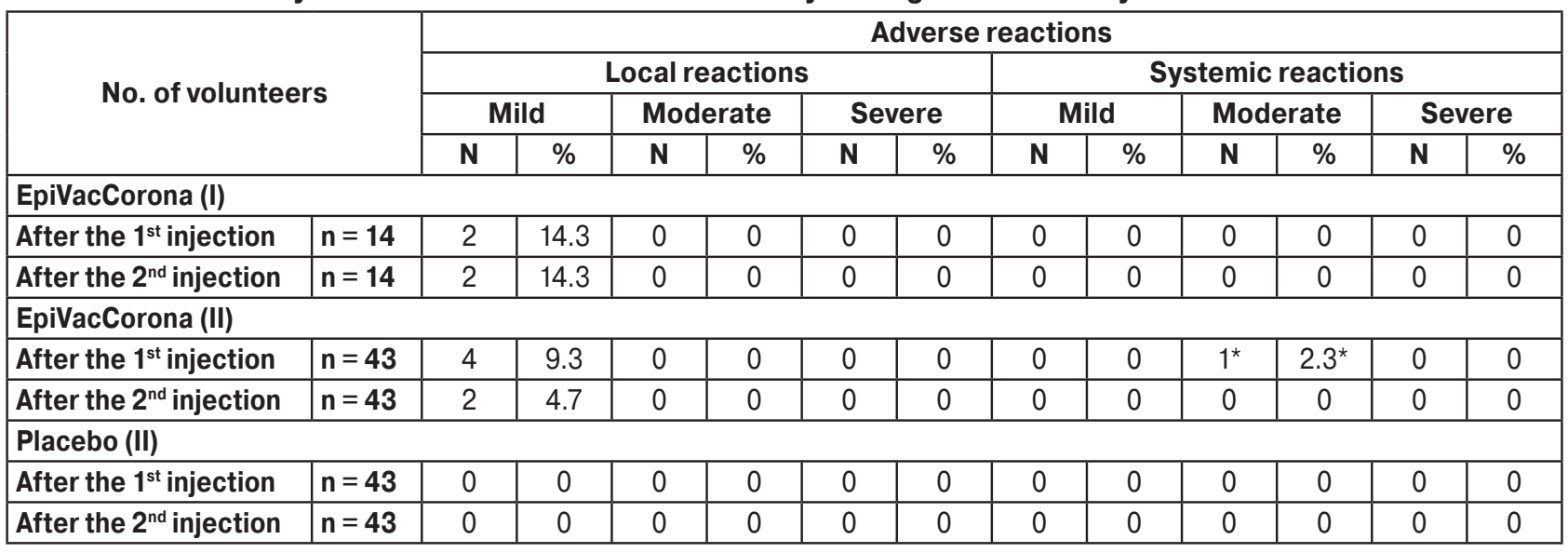

Note. ${ }^{*}-$ The observed reactions were not attributed to vaccination. 


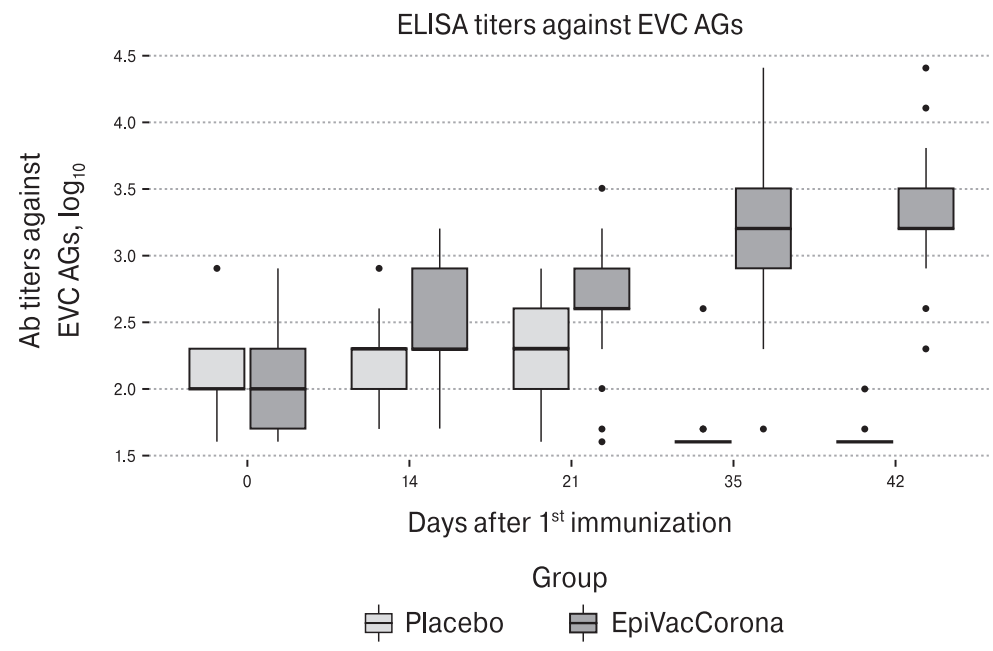

Figure 2. Specific antibodies to EpiVacCorona antigens, 14, 21, 35 and 42 days after the first immunization, $\log _{10}$

metric mean titer reaching 1:2475 (Fig. 2, Table 3). Geometric mean titers to whole SARS-CoV-2 antigens were significantly lower: 1:105 and 1:156, on days 35 and 42 following the first immunization, respectively. IgG seroconversion to native coronavirus antigens was reported in $82.1 \%$ of volunteers on day 42 day following the first immunization (Fig. 3, Table 3). IgM seroconversion, when measured to whole coronavirus proteins, was minimal and amounted to $5.3 \%$ on days 14 and 21 following the first immunization, decreasing to $1.8 \%$ by the $35^{\text {th }}$ day following the first immunization (data not shown).

Neutralization assay on Vero E6 cells was used to measure the level of neutralizing antibodies. On day 42 following the first vaccination, $100 \%$ of the volunteers had neutralizing antibodies with titers ranging from 1:20 to 1:160. Geometric mean titers were 1:68 and $1: 48$, on days 35 and 42 following the first immunization, respectively. None of placebo group volunteers had seroconversion (Fig. 4, Table 2).

\section{Discussion}

Clinical study of EpiVacCorona showed that the maximum value of vaccine antigen seroconversion was reported in $100 \%$ of volunteers on the $42^{\text {nd }}$ day following the first injection. By this time, geometric mean titer to the vaccine antigen in the group of vaccinated volunteers reached the value of 1:2475, ranging from 1:800 to 1:25 600 .

High immunogenicity of EpiVacCorona was observed during preclinical studies (data not shown, the paper is under review). The GMTs of antibodies to vaccine antigens in the sera of hamsters vaccinated with a dose of $260 \mu \mathrm{g}$ were 1:11 943 two weeks following the second inoculation. By the same time, $100 \%$ of vaccinated ferrets developed high levels of specific antibodies, with GMTs ranging from 1:9051 to 1:10 159 in three groups of ferrets immunized with three series of EpiVacCorona. In primates, the vaccine induces high titers of antibodies
A

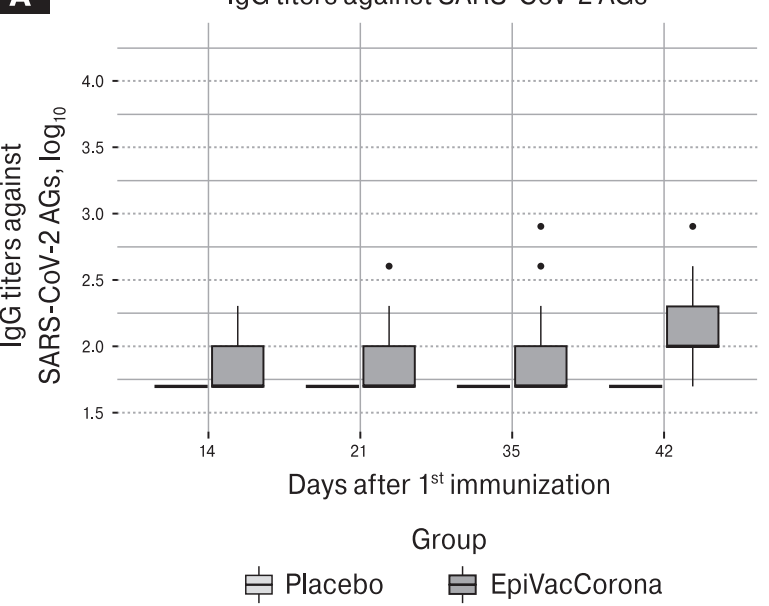

B

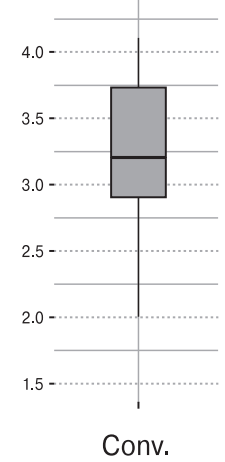

Figure 3. A) Specific antibodies to SARS-CoV-2 antigens in volunteer sera 14, 21, 35 and 42 days after the first immunization, $\log _{10}$. B) Specific antibodies to SARS-CoV-2 antigens in convalescent sera, $\log _{10}$ 
Table 3. Immunogenicity and virus-neutralization studies results

\begin{tabular}{|c|c|c|c|c|c|c|c|c|c|c|c|}
\hline Variable & Time & Vac. & $\mathbf{N}$ & Min & Max & Mean & SD & Gmean & Med & Q1 & Q3 \\
\hline Vac & 0 & 0 & 43 & 40 & 800 & 139.3 & 117.99 & $115.01[96.04,137.74]$ & 100 & 100 & 200 \\
\hline Vac & 0 & 1 & 57 & 40 & 800 & 153.51 & 156.26 & $110.74[90.36,135.72]$ & 100 & 50 & 200 \\
\hline Vac & 14 & 0 & 43 & 50 & 800 & 213.95 & 143.23 & $175.8[144.09,214.49]$ & 200 & 100 & 200 \\
\hline Vac & 14 & 1 & 57 & 50 & 1600 & 383.33 & 313.58 & $284.57[231.59,349.66]$ & 200 & 200 & 800 \\
\hline Vac & 21 & 0 & 43 & 40 & 800 & 243.95 & 155.84 & $195.78[157.24,243.77]$ & 200 & 100 & 400 \\
\hline Vac & 21 & 1 & 57 & 40 & 3200 & 701.58 & 604.12 & $478.17[370.71,616.76]$ & 400 & 400 & 800 \\
\hline Vac & 35 & 0 & 43 & 40 & 400 & 49.3 & 54.83 & $43.09[38.64,48.04]$ & 40 & 40 & 40 \\
\hline Vac & 35 & 1 & 57 & 50 & 25600 & 4425.44 & 6116.2 & $2065.5[1454.96,2932.24]$ & 1600 & 800 & 3200 \\
\hline Vac & 42 & 0 & 32 & 40 & 100 & 44.06 & 14.78 & $42.65[39.3,46.29]$ & 40 & 40 & 40 \\
\hline Vac & 42 & 1 & 54 & 200 & 51200 & 5237.04 & 8745.98 & $2475.47[1795.72,3412.52]$ & 1600 & 1600 & 5600 \\
\hline IgG_vir & 14 & 0 & 43 & 50 & 50 & 50 & 0 & $50[50,50]$ & 50 & 50 & 50 \\
\hline IgG_vir & 14 & 1 & 57 & 50 & 200 & 72.81 & 29.99 & $67.76[61.41,74.77]$ & 50 & 50 & 100 \\
\hline IgG_vir & 21 & 0 & 43 & 50 & 50 & 50 & 0 & $50[50,50]$ & 50 & 50 & 50 \\
\hline IgG_vir & 21 & 1 & 57 & 50 & 400 & 91.23 & 55.2 & $81.32[72.11,91.71]$ & 100 & 50 & 100 \\
\hline IgG_vir & 35 & 0 & 43 & 50 & 50 & 50 & 0 & $50[50,50]$ & 50 & 50 & 50 \\
\hline IgG_vir & 35 & 1 & 56 & 50 & 800 & 138.39 & 148.01 & $105.08[88.08,125.36]$ & 100 & 50 & 100 \\
\hline IgG_vir & 42 & 0 & 42 & 50 & 50 & 50 & 0 & $50[50,50]$ & 50 & 50 & 50 \\
\hline IgG_vir & 42 & 1 & 56 & 50 & 51200 & 1533.93 & 7565.35 & $156.14[111.31,219.03]$ & 100 & 100 & 200 \\
\hline Neutr & 35 & 0 & 38 & 10 & 20 & 10.53 & 2.26 & $10.37[9.85,10.92]$ & 10 & 10 & 10 \\
\hline Neutr & 35 & 1 & 57 & 20 & 160 & 74.04 & 45.03 & $61.97[52.72,72.84]$ & 80 & 40 & 80 \\
\hline Neutr & 42 & 0 & 43 & 10 & 10 & 10 & 0 & $10[10,10]$ & 10 & 10 & 10 \\
\hline Neutr & 42 & 1 & 56 & 20 & 80 & 52.5 & 21.43 & $48.16[42.94,54.01]$ & 40 & 40 & 80 \\
\hline
\end{tabular}

Notes. Variables: Vac — reciprocal titers of serum antibodies specific to vaccine antigens; IgG vir — reciprocal titers of serum antibodies specific to SARS-CoV-2 virions; Neutr - reciprocal virus-neutralizing serum titers. Time - the time in days since the 1st injection. Vac. - 1 in EpiVacCorona group and 0 in placebo group. $\mathrm{N}-$ the number of volunteers. Min, Max and Mean - are the minimal, maximal and average values respectively. $\mathrm{SD}$ is standard deviation. Gmean is the geometric mean value and its 95\% confidence interval. Med, Q1 and Q2 are the median value and the $1^{\text {st }}$ and the $3^{\text {rd }}$ quartile values.

to the vaccine antigens and the whole-virion antigen of coronavirus in $100 \%$ of animals $2-3$ weeks following the first vaccination. Four weeks following the first vaccination, GMTs to the vaccine antigen reach 1:12 800 and 1:11 143, in rhesus macaques and green monkeys, respectively. $100 \%$ of experimental group animals had a titer of antibodies specific to the vaccine antigen, ranging from 1:6400 to 1:25 600 . However, neutralizing antibodies were reported 14 weeks following the first vaccination and disappeared 4 weeks before coronavirus challenge. After the challenge of vaccinated animals, none of the primates showed focal infiltrative changes in lungs typical for viral pneumonias, while placebo animals showed extensive lung tissue damage and signs of viral pneumonia (pleurisy, cardiomegaly). In contrast to our findings in preclinical studies in primates, $100 \%$ of the volunteers had neutralizing antibody titers of $1: 20$ to $1: 160$ after two vaccinations, with GMT of 1:68 on day 35 after the 1st injection. Thus, EpiVacCorona Vaccine was found to be immunogenic and capable of inducing potentially protective immunity and virus-neutralizing antibodies in human volunteers.

Peptides included into EpiVacCorona overlap with epitopes described by VirScan, and the most notable among them is the epitope S454-463, which is located to receptor binding domain and overlaps the binding site of virus-neutralizing antibody
CB6 [18]. In another SARS-CoV-2 B-cell epitope study with peptide microarrays, there was found similar overlapping epitope S456-460, which was previously identified as the epitope of neutralizing antibody B38 isolated from a convalescent patient [24].

Looking beyond the spike protein, which is the primary target of the majority of current SARS-

Virus-neutralization titers
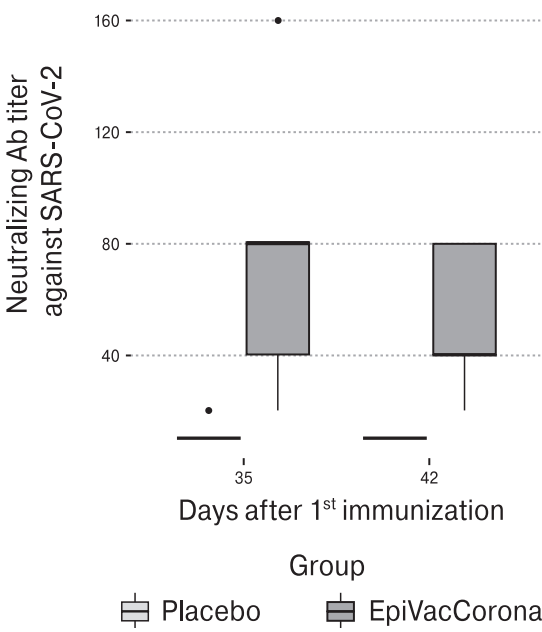

Figure 4. Virus-neutralizing antibodies (reverse titer) in volunteer sera $\mathbf{3 5}$ and $\mathbf{4 2}$ days after the first immunization 
CoV-2 immunoassays and vaccines, many current serological assays use recombinant protein $\mathrm{N}$, since it is produced in vast amounts by a replicating virus [13]. Protein $\mathrm{N}$ was even proposed for a mass-spectrometry-based method for specific and sensitive SARSCoV-2 virus detection in nasopharynx epithelial swabs, since such an approach was able to confidently identify the virus in patient samples with even the lowest viral loads [14]. Detailed overviews of the epitope landscape within SARS-CoV-2 confirmed that protein $\mathrm{N}$ is a valuable marker bearing many $\mathrm{B}$-cell epitopes recognized by antibodies from exposed patients [13, 18, 21]. Interestingly, even with a single protein $\mathrm{N}$ epitope located to region 155-171, it was possible to achieve $92 \%$ sensitivity and $100 \%$ specificity in discriminating healthy individuals from infected ones [13]. Protein N was proposed as a valuable component of future SARS-CoV-2 vaccines [4], and it was also shown to induce T-cell immune responses. $\mathrm{N}$-specific T cells were observed in SARS-CoV-2 N immunized mice and COVID-19 convalescents [6, 8]. Recently, it was shown that intranasal inoculation of recombinant adenovirus expressing SARS-CoV-2 protein $\mathrm{N}$ induce local and systemic $\mathrm{T}$-cell immune responses in mice. It induced $\mathrm{CD}^{+} \mathrm{CTL}$ responses in lungs and $\mathrm{CD}^{+} \mathrm{T}$-cell responses in spleen of immunized animals. $\mathrm{N}$ protein-specific $\mathrm{CD}^{+} \mathrm{T}$-cell responses were also associated with humoral immune response [8]. EpiVacCorona Vaccine contains SARSCoV-2 protein $\mathrm{N}$ that was selected to be used as a carrier for peptide antigens due to its high level of conservation and immunogenicity, as a valuable source of $\mathrm{CD}^{+}{ }^{+} \mathrm{T}$-cell epitopes according to our previous experience. Recent findings support the conclusion that protein $\mathrm{N}$, although unable to raise virus-neutralizing responses, still might be important for developing virus-specific T- and B-memory cells; this is especially important as memory $\mathrm{T}$ cells might persist longer than antibodies or memory B cells, as it was observed for SARS-CoV [6].

Besides, it is also important to point out that high titers of virus-specific antibodies are not necessarily associated with protection from COVID-19. During the current pandemic, many research groups have reported that individuals with mild or asymptomatic disease have low antibody titers towards SARSCoV-2 antigens. For example, in one such study, it was found that $87.5 \%$ of asymptomatic and $23.5 \%$ of mild patients had no detectable antibodies against SARS-CoV-2 [20]. The rapid decline in virus-specific IgG titers after viral infection has been described in numerous reports, and it has also been shown that up to $40 \%$ of asymptomatic individuals become seronegative as soon as in 3 months [6].

EpiVacCorona Vaccine demonstrated low reactogenicity. Only four (9.3\%) and two (4.7\%) volunteers developed mild local reactions after the first and the second injections of the vaccine, respectively. The duration of symptoms after the first and the second vaccinations was 1-2 days. Post-vaccination reactions were mild, short-lived and caused no discomfort to the volunteers. No other manifestations of reactogenicity were reported. The vaccine was shown to be safe and well tolerated. EpiVacCorona peptide vaccine was found to induce virus-specific and neutralizing antibodies in $100 \%$ of volunteers at levels that, as it was shown in preclinical studies (in hamsters, ferrets and primates), provided a 5-7day reduction of virus carriage duration and prevented pneumonia (the publication is under review). The number of volunteers enrolled and the number of laboratory-confirmed COVID-19 cases is not sufficient to draw conclusions about vaccine efficacy.

\section{Supplementary materials}

Supplementary Tables are available at: http://dx.doi.org/10.15789/2220-7619-ASB-1699

\section{Acknowledgements}

This research was funded by the Federal Service for Surveillance on Consumer Rights Protection and Human Wellbeing (Rospotrebnadzor).

\section{Conflicts of interest}

ABR, MPB, EDD, EAN, OVP, OGP, EVG, RAM, and EAR report holding a patent RU2738081 on peptide immunogens and vaccine composition. EAR and ESS declare employment at EpiVac LLC. All other authors declare no competing interests.

All authors attest they meet the ICMJE criteria for authorship.

\section{References}

1. Ганеева Л.А., Скрипова В.С., Касатова Л.В., Набиуллина Р.М., Абрамова З.И. Оценка некоторых биохимических параметров энергетического обмена у студентов-легкоатлетов после продолжительной нагрузки // Ученые записки Казанского университета. Серия «Естественные науки». 2013. Т. 155, № 1. C. 40-49. [Ganeeva L.A., Skripova V.S., Kasatova L.V., Nabiullina R.M., Abramova Z.I. Assessment of some biochemical parameters of energy metabolism in studentathletes after prolonged exercise. Uchenye Zapiski Kazanskogo Universiteta. Seriya "Estestvennye Nauki" = Kazan University Bulletin. Natural Sciences Series, 2013, vol. 155, pp. 40-49(In Russ.)]

2. Методы определения показателей качества иммунобиологических препаратов для профилактики и диагностики гриппа: Методические указания МУ 3.3.2.1758-03 // М.: Федеральный центр госсанэпиднадзора Минздрава России, 2005. $44 \mathrm{c}$. [Methods for determining the quality indicators of immunobiological products for the prevention and diagnosis of influenza. Methodology Guidelines MU 3.3.2.1758-03. Moscow: Federal Centre of the Federal Service for Surveillance of Consumer Rights Protection and Human Wellbeing of the Ministry of Healthcare of the Russian Federation, 2005. 44 p. (In Russ.)] 
3. Berger A., Drosten C., Doerr H.W., Sturmer M., Preiser W. Severe acute respiratory syndrome (SARS) - paradigm of an emerging viral infection. J. Clin. Virol., 2004, vol. 29, pp. 13-22. doi: 10.1016/j.jcv.2003.09.011

4. Dutta N.K., Mazumdar K., Gordy J.T. The nucleocapsid protein of SARS-CoV-2: a target for vaccine development. J. Virol., 2020, vol. 94, no. 13: e00647-20. doi: 10.1128/JVI.00647-20

5. Elbe S., Buckland-Merrett G. Data, disease and diplomacy: GISAID's innovative contribution to global health. Global Challenges (Hoboken, NJ), 2017, vol. 1, no. 1, pp. 33-46. doi: 10.1002/gch2.1018

6. Ferretti A.P., Kula T., Wang Y., Nguyen D.M.V., Weinheimer A., Dunlap G.S., Xu Q., Nabilsi N., Perullo C.R., Cristofaro A.W., Whitton H.J., Virbasius A., Olivier K.J. Jr, Buckner L.R., Alistar A.T., Whitman E.D., Bertino S.A., Chattopadhyay S., MacBeath G. Unbiased screens show CD8 ${ }^{+}$T cells of COVID-19 patients recognize shared epitopes in SARS-CoV-2 that largely reside outside the spike protein. Immunity, 2020, vol. 53, no. 5: 1095-1107.e3. doi: 10.1016/j.immuni.2020.10.006

7. Goncharova E., Ryzhikov E., Poryvaev V., Bulychev L., Karpyshev N., Maksyutov A., Ryzhikov A. Intranasal immunization with inactivated tick-borne encephalitis virus and the antigenic peptide 89-119 protects mice against intraperitoneal challenge. Int. J. Med. Microbiol., 2006, vol. 296, pp. 195-201. doi: 10.1016/j.ijmm.2006.02.002

8. He J., Huang J.R., Zhang Y.L., Zhang J. SARS-CoV-2 nucleocapsid protein intranasal inoculation induces local and systemic T cell responses in mice. J. Med. Virol., 2021, vol. 93, pp. 1923-1925. doi: 10.1002/jmv.26769

9. Kaur S.P., Gupta V. COVID-19 vaccine: a comprehensive status report. Virus Res., 2020, vol. 288: 198114. doi: 10.1016/j.virusres.2020.198114

10. Khuroo M.S., Khuroo M., Khuroo M.S., Sofi A.A., Khuroo N.S.. COVID-19 Vaccines: a race against time in the middle of death and devastation! J. Clin. Exp. Hepatol., 2020, vol.10, no. 6, pp. 610-621. doi: 10.1371/journal.pntd.0002787

11. Maksyutov A.Z., Bachinskii A.G., Bazhan S.I., Ryzhikov E.A. Design of safe AIDS vaccines based on search for local similarities between HIV-1 and human proteins. In: AIDS Vaccines and Related Topics. Kerala: Research Signpost, 2004, pp. 47-62.

12. Patent No. WO 2004/031212. 2004 A1. Russian Federation, Int. Cl. WO 2004/031212. 2004 A1. Antigenic peptides. No. 2003/ 000421; application: 2003.09.25: date of publication 2004.04.15 / Maksyutov A.Z., Ryzhikov A.B., Kolobov A.A., Maksyutov Z.A. Proprietors: Gosydarstvenyi Nauchnyi Tsentr Virusologii I Biotekhnologii "Vector” Rospotrebnadzora (GNII VB "Vector"). $84 \mathrm{p}$.

13. Musicò A., Frigerio R., Mussida A., Barzon L., Sinigaglia A., Riccetti S., Gobbi F., Piubelli C., Bergamaschi G., Chiari M., Gori A., Cretich M. SARS-CoV-2 epitope mapping on microarrays highlights strong immune-response to $\mathrm{N}$ protein region. Vaccines, 2021, vol. 9, no. 1: 35. doi: 10.3390/vaccines9010035

14. Nikolaev E.N., Indeykina M.I., Brzhozovskiy A.G., Bugrova A.E., Kononikhin A.S., Starodubtseva N.L., Petrotchenko E.V., Kovalev G.I., Borchers C.H., Sukhikh G.T. Mass-spectrometric detection of SARS-CoV-2 virus in scrapings of the epithelium of the nasopharynx of infected patients via nucleocapsid N protein. J. Proteome Res., 2020, vol. 19, no. 11, pp. $4393-4397$. doi: 10.1021/acs.jproteome.0c00412

15. Omrani A.S., Saad M.M., Baig K., Bahloul A., Abdul-Matin M., Alaidaroos A.Y., Almakhlafi G.A., Albarrak M.M., Memish Z.A., Albarrak A.M. Ribavirin and interferon alfa-2a for severe Middle East respiratory syndrome coronavirus infection: a retrospective cohort study. Lancet Infect. Dis., 2014, vol. 14, no. 11, pp. 1090-1095. doi: 10.1016/S1473-3099(14)70920-X

16. R: a language and environment for statistical computing (v.4.0.2). Global Diversity Information Facility. URL: https://www.gbif. org/ru/tool/81287/r-a-language-and-environment-for-statistical-computing

17. Schiffman F.J. Hematologic pathophysiology. Philadelphia: Lippincott-Raven, 2009. 388 p.

18. Shrock E., Fujimura E., Kula T., Timms R.T., Lee I.H., Leng Y., Robinson M.L., Sie B.M., Li M.Z., Chen Y., Logue J., Zuiani A., McCulloch D., Lelis F.J.N., Henson S., Monaco D.R., Travers M., Habibi S., Clarke W.A., Caturegli P., Laeyendecker O., Piechocka-Trocha A., Li J.Z., Khatri A., Chu H.Y.; MGH COVID-19 Collection \& Processing Team, Villani A.C., Kays K., Goldberg M.B., Hacohen N., Filbin M.R., Yu X.G., Walker B.D., Wesemann D.R., Larman H.B., Lederer J.A., Elledge S.J. Viral epitope profiling of COVID-19 patients reveals cross-reactivity and correlates of severity. Science, 2020, vol. 370, no. 652: eabd4250. doi: 10.1126/science.abd4250

19. Song W., Gui M., Wang X., Xiang Y. Cryo-EM structure of the SARS coronavirus spike glycoprotein in complex with its host cell receptor ACE2. PLoS Pathog., 2018, vol. 14, no. 8: e1007236. doi: 10.1371/journal.ppat.1007236

20. Takeshita M., Nishina N., Moriyama S., Takahashi Y., Uwamino Y., Nagata M., Aoki W., Masaki K., Ishii M., Saya H., Kondo Y., Kaneko Y., Suzuki K., Fukunaga K., Takeuchi T.; Keio Donner project. Incomplete humoral response including neutralizing antibodies in asymptomatic to mild COVID-19 patients in Japan. Virology, 2021, vol. 555, pp. 35-43. doi: 10.1016/ j.virol.2020.12.020

21. Wang H., Wu X., Zhang X., Hou X., Liang T., Wang D., Teng F., Dai J., Duan H., Guo S., Li Y., Yu X. SARS-CoV-2 proteome microarray for mapping COVID-19 antibody interactions at amino acid resolution. ACS Cent. Sci., 2020, vol. 6, no. 12, pp. 22382249. doi: 10.1021/acscentsci.0c00742

22. Wang Q., Zhang L., Kuwahara K., Li L., Liu Z., Li T., Zhu H., Liu J., Xu Y., Xie J., Morioka H., Sakaguchi N., Qin C., Liu G. Immunodominant SARS coronavirus epitopes in humans elicited both enhancing and neutralizing effects on infection in nonhuman primates. ACS Infect. Dis., 2016, vol. 2, no. 5, pp. 361-376. doi: 10.1021/acsinfecdis.6b00006

23. WHO declares public health emergency for novel coronavirus. Medscape, 2020. URL: https://www.medscape.com/viewarticle/924596

24. Wu Y., Wang F., Shen C., Peng W., Li D., Zhao C., Li Z., Li S., Bi Y., Yang Y., Gong Y., Xiao H., Fan Z., Tan S., Wu G., Tan W., Lu X., Fan C., Wang Q., Liu Y., Zhang C., Qi J., Gao G.F., Gao F., Liu L. A noncompeting pair of human neutralizing antibodies block COVID-19 virus binding to its receptor ACE2. Science, 2020, vol. 368, no. 6496, pp. 1274-1278. doi: 10.1126/science. $a b c 2241$

25. Zhu N., Zhang D., Wang W., Li X., Yang B., Song J., Zhao X., Huang B., Shi W., Lu R., Niu P., Zhan F., Ma X., Wang D., Xu W., Wu G., Gao G.F., Tan W.; China Novel Coronavirus Investigating and Research Team. A novel coronavirus from patients with pneumonia in China 2019. N. Engl. J. Med., 2020, vol. 382, no. 8, pp. 727-733. doi: 10.1056/NEJMoa2001017 


\section{Авторы:}

Рыжиков А.Б., к.б.н., зав. отделом зоонозных инфекций и гриппа ФБУН ГНЦ ВБ «Вектор» Роспотребнадзора, р.п. Кольцово, Новосибирская область, Россия;

Рыжиков Е.А., директор ООО «ЭпиВак», р.п. Кольцово, Новосибирская область, Россия;

Богрянцева М.П., к.б.н., зав. отделом биологического и технологического контроля ФБУН ГНЦ ВБ «Вектор Роспотребнадзора, р.п. Кольцово, Новосибирская область, Россия;

Усова С.В., К.М.Н., ведущий научный сотрудник ФБУН ГНЦ ВБ «Вектор» Роспотребнадзора, р.п. Кольцово, Новосибирская область, Россия;

Даниленко Е.Д., к.б.н., директор ИМБТ ФБУН ГНЦ ВБ «Вектор» Роспотребнадзора, р.п. Кольцово, Новосибирская область, Россия Нечаева Е.А., к.М.Н., зам. гендиректора ФБУН ГНЦ ВБ «Вектор» Роспотребнадзора, р.п. Кольцово, Новосибирская область, Россия;

Пьянков О.В., к.б.н., зав. отделом «Коллекция микроорганизмов» ФБУН ГНЦ ВБ «Вектор» Роспотребнадзора, р.п. Кольцово, Новосибирская область, Россия;

Пьянкова О.Г., ведущий научный сотрудник ФБУН ГНЦ ВБ «Вектор» Роспотребнадзора, р.п. Кольцово, Новосибирская область, Россия;

Гудымо А.C., младший научный сотрудник ФБУН ГНЦ ВБ «Вектор» Роспотребнадзора, р.п. Кольцово, Новосибирская область, Россия;

Боднев С.А., к.м.Н., ведущий научный сотрудник ФБУНГНЦ ВБ «Вектор» Роспотребнадзора, р.п. Кольцово, Новосибирская область, Россия;

Онхонова Г.С., младший научный сотрудник ФБУН ГНЦ ВБ «Вектор» Роспотребнадзора, р.п. Кольцово, Новосибирская область, Россия;

Слепцова Е.С., начальник отдела контроля качества ООО «ЭпиВак», р.п. Кольцово, Новосибирская область, Россия; Кузубов В.И., начальник ФГБУЗ МСЧ № 163 ФМБА России р.п. Кольцово, Новосибирская область, Россия; Рындюк Н.Н., зам. начальника по медицинской части, врачневролог ФГБУЗ МСЧ № 163 ФМБА России, р.п. Кольцово Новосибирская область, Россия;

Гинько 3.И., зав. стационаром особо опасных инфекций противочумной станции, врач-инфекционист ФГБУЗ МСЧ № 163 ФМБА России, р.п. Кольцово, Новосибирская область, Россия; Петров В.Н., зав. информационно-аналитическим отделом ФБУН ГНЦВБ «Вектор» Роспотребнадзора, р.п. Кольцово, Новосибирская область, Россия;

Моисеева А.А., младший научный сотрудник ФБУН ГНЦ ВБ «Вектор» Роспотребнадзора, р.п. Кольцово, Новосибирская область, Россия;

Торжкова П.Ю., стажер-исследователь ФБУН ГНЦ ВБ «Вектор» Роспотребнадзора, р.п. Кольцово, Новосибирская область, Россия; Пьянков С.А., ведущий научный сотрудник ФБУН ГНЦ ВБ «Вектор» Роспотребнадзора, р.п. Кольцово, Новосибирская область, Россия;

Трегубчак Т.В., ведущий научный сотрудник ФБУНГНЦ ВБ «Вектор» Роспотребнадзора, р.п. Кольцово, Новосибирская область, Россия;

Антонец Д.В., к.б.н., старший научный сотрудник ФБУНГНЦ ВБ «Вектор» Роспотребнадзора, р.п. Кольцово, Новосибирская область, Россия;

Гаврилова Е.В., к.б.н., зам. гендиректора по научной работе ФБУН ГНЦ ВБ «Вектор» Роспотребнадзора, р.п. Кольцово, Новосибирская область, Россия;

Максютов Р.А., д.б.н., гендиректор ФБУН ГНЦ ВБ «Вектор» Роспотребнадзора, р.п. Кольцово, Новосибирская область, Россия.

\section{Authors:}

Ryzhikov A.B., PhD (Biology), Head of the Department of Zoonotic Infections and Influenza, State Scientific Center of Virology and Biotechnology "Vector" of Rospotrebnadzor, Koltsovo, Novosibirsk Region, Russian Federation;

Ryzhikov E.A., Director of LLC "EpiVac", Koltsovo, Novosibirsk Region, Russian Federation;

Bogryantseva M.P., PhD (Biology), Head of the Biological and Technology Supervision Department, State Scientific Center of Virology and Biotechnology "Vector" of Rospotrebnadzor, Koltsovo, Novosibirsk Region, Russian Federation;

Usova S.V., PhD (Medicine), Leading Researcher, State Scientific Center of Virology and Biotechnology "Vector" of Rospotrebnadzor, Koltsovo, Novosibirsk Region, Russian Federation;

Danilenko E.D., PhD (Biology), Director of the Medical Biotechnology Institute, State Scientific Center of Virology and Biotechnology "Vector" of Rospotrebnadzor, Koltsovo, Novosibirsk Region, Russian Federation; Nechaeva E.A., PhD (Medicine), Deputy Director of the State Scientific Center of Virology and Biotechnology "Vector" of Rospotrebnadzor, Koltsovo, Novosibirsk Region, Russian Federation;

Pyankov O.V., PhD (Biology), Head of the Microorganisms Collection Department, State Scientific Center of Virology and Biotechnology "Vector" of Rospotrebnadzor, Koltsovo, Novosibirsk Region, Russian Federation;

Pyankova O.G., Leading Researcher, State Scientific Center of Virology and Biotechnology "Vector" of Rospotrebnadzor, Koltsovo, Novosibirsk Region, Russian Federation;

Gudymo A.S., Junior Researcher, State Scientific Center of Virology and Biotechnology "Vector" of Rospotrebnadzor, Koltsovo, Novosibirsk Region, Russian Federation;

Bodnev S.A., PhD (Medicine), Leading Researcher, State Scientific Center of Virology and Biotechnology "Vector" of Rospotrebnadzor, Koltsovo, Novosibirsk Region, Russian Federation;

Onkhonova G.S., Junior Researcher, State Scientific Center of Virology and Biotechnology "Vector" of Rospotrebnadzor, Koltsovo, Novosibirsk Region, Russian Federation;

Sleptsova E.S., Head of the Quality Control Department, LLC "EpiVac", Koltsovo, Novosibirsk Region, Russian Federation;

Kuzubov V.I., Head of the Medical Unit No. 163 of the Federal Medical and Biological Agency of Russia, Koltsovo, Novosibirsk Region, Russian Federation;

Ryndyuk N.N., Deputy Head of the Medical Unit, Neurologist, Medical Unit No. 163 of the Federal Medical and Biological Agency of Russia, Koltsovo, Novosibirsk Region, Russian Federation;

Ginko Z.I., Head of the Especially Dangerous Infections Facility, Plague Control Station, Infectologist, Medical Unit No. 163 of the Federal Medical and Biological Agency of Russia, Koltsovo, Novosibirsk Region, Russian Federation;

Petrov V.N., Head of the Information and Analytical Department, State Scientific Center of Virology and Biotechnology "Vector" of Rospotrebnadzor, Koltsovo, Novosibirsk Region, Russian Federation; Moiseeva A.A., Junior Researcher, State Scientific Center of Virology and Biotechnology "Vector" of Rospotrebnadzor, Koltsovo, Novosibirsk Region, Russian Federation;

Torzhkova P.Yu., Researcher, State Scientific Center of Virology and Biotechnology "Vector" of Rospotrebnadzor, Koltsovo, Novosibirsk Region, Russian Federation;

Pyankov S.A., Leading Researcher, State Scientific Center of Virology and Biotechnology "Vector" of Rospotrebnadzor, Koltsovo, Novosibirsk Region, Russian Federation;

Tregubchak T.V., Leading Researcher, State Scientific Center of Virology and Biotechnology "Vector" of Rospotrebnadzor, Koltsovo, Novosibirsk Region, Russian Federation;

Antonec D.V., PhD (Biology), Senior Researcher, State Scientific Center of Virology and Biotechnology "Vector" of Rospotrebnadzor, Koltsovo, Novosibirsk Region, Russian Federation;

Gavrilova E.V., PhD (Biology), Deputy Director for Academic Affairs, State Scientific Center of Virology and Biotechnology "Vector" of Rospotrebnadzor, Koltsovo, Novosibirsk Region, Russian Federation; Maksyutov R.A., PhD, MD (Biology), Director General of the State Scientific Center of Virology and Biotechnology "Vector" of Rospotrebnadzor, Koltsovo, Novosibirsk Region, Russian Federation
Поступила в редакцию 04.03.2021

Принята к печати 17.03.2021
Received 04.03.202

Accepted 17.03.202 